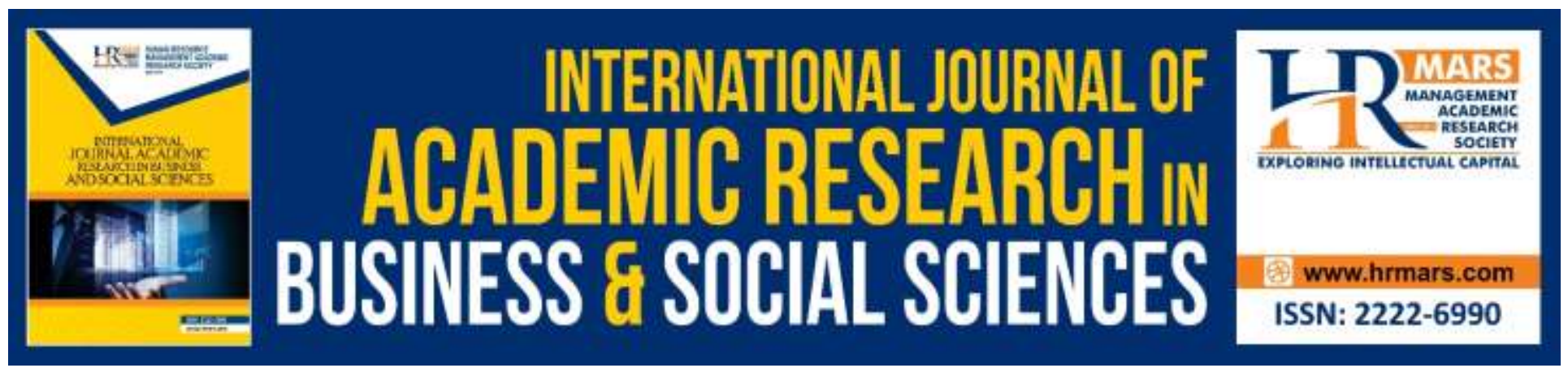

\title{
Exploring Researchers' Attitude toward the Using of Institutional Repositories at University Putra Malaysia
}

\author{
Shahla Asadi, Rusli Abdullah, Yusmadi Yah Jusoh, Fatimah Sidi
}

To Link this Article: http://dx.doi.org/10.6007/IJARBSS/v9-i13/6622

DOI:10.6007/IJARBSS/v9-i13/6622

Received: 22 September 2019, Revised: 17 October 2019, Accepted: 02 November 2019

Published Online: 23 November 2019

In-Text Citation: (Asadi, Abdullah, Jusoh \& Sidi, 2019)

To Cite this Article: Asadi, S., Abdullah, R., Jusoh, Y. Y., Sidi, F. (2019). Exploring Researchers' Attitude toward the Using of Institutional Repositories at University Putra Malaysia. International Journal of Academic Research in Business and Social Sciences, 9(13), 1012-1024.

Copyright: (C) 2019 The Author(s)

Published by Human Resource Management Academic Research Society (www.hrmars.com)

This article is published under the Creative Commons Attribution (CC BY 4.0) license. Anyone may reproduce, distribute, translate and create derivative works of this article (for both commercial and non-commercial purposes), subject to full attribution to the original publication and authors. The full terms of this license may be seen

at: http://creativecommons.org/licences/by/4.0/legalcode

Special Issue: Revolutionizing Education: Challenges, Innovation, Collaboration, 2019, Pg. 1012 - 1024 http://hrmars.com/index.php/pages/detail/IJARBSS

JOURNAL HOMEPAGE

Full Terms \& Conditions of access and use can be found at http://hrmars.com/index.php/pages/detail/publication-ethics 


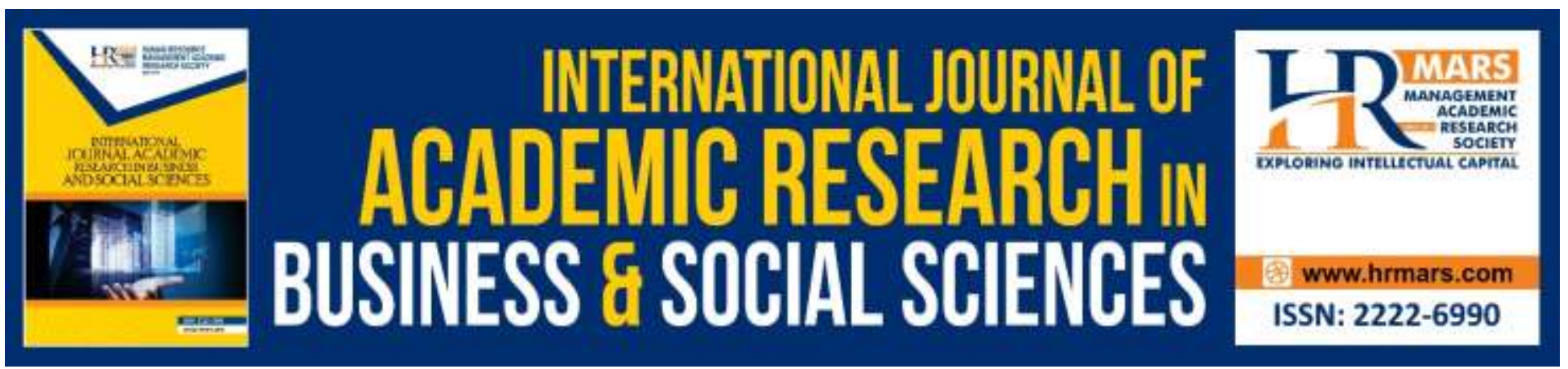

\title{
Exploring Researchers' Attitude toward the Using of Institutional Repositories at University Putra Malaysia
}

\author{
Shahla Asadi, Rusli Abdullah, Yusmadi Yah Jusoh, Fatimah \\ Sidi \\ Faculty of Computer Science and Information Technology, University Putra Malaysia, \\ Malaysia \\ Email: asadi.shahla2003@gmail.com
}

\begin{abstract}
One of the recent resources used at university libraries is institutional repositories (IRs) which have been considered one of the disseminating and preserving ways for academic research publications. IRs have received considerable attention from researchers across disciplines and around the globe. While that have potentially increased public value, ranking, prestige and visibility of researchers and relevant universities. In this regard, the main aim of this paper is to determine researchers' attitude concerning the utilization of institutional repositories via a modified Technology Acceptance Model at the University Putra Malaysia (UPM). A structured questionnaire was designed, and a survey was taken using a sample of 90 researchers. The results showed that researchers were aware of the institutional repository and had an attitude an interest of presenting their research to their university repository. They were under the impression that by presenting their research to the institutional repository, their university ranking will increase in addition to the citation impact of their research work.
\end{abstract}

Keywords: Institutional Repository, IR, Factors, Attitude, Technology Acceptance Model, TAM.

\section{Introduction}

Institutional Repositories (IRs) are extensively gaining popularity and becoming a vital part of academic institutions. Considerable attention has been paid from scholars from various disciplines worldwide. IRs are currently defined as digital collections for the capture and maintain of the intellectual output of a single or multi-university community (Bangani, 2018). IRs have gained eminence in developed and third world countries since they provide a solution for content management in universities (Ukwoma and Dike, 2017). Anenene et al. (2017) defined an IR as a series of services offered by a university to its members with the aim of managing, organizing and diffusing digital work produced by these members. Therefore, an IR can be considered a digital archive that presents a platform for universities to archive relevant intellectual output. IRs may consist of learning 
objects, administrative documents, conference proceedings, seminar papers, course notes, projects, dissertations, these and various other types of grey literature.

Ngure et al. (2015) mentioned that IRs was embraced by institutions worldwide in order to accumulate, showcase and conserve their scholarly and intellectual output. IRs consists of original research and various other types of intellectual products stemming from a university's population from diverse knowledge fields (Scholastica et al., 2017). The progression of IRs distribution is fairly new in Malaysia. Wirba et al. (2013) stated that only a few Malaysian research universities were using IRs to increase visibility. Moreover, Ukwoma and Dike (2017) mentioned that researcher's inclination to implement IRs as a means to archive their research products and to cooperate with co-workers are required for IR sustainability.

Researchers' attitude regarding content's submission to their IRs can be positive or negative, which is dependent on the mechanism approved by university management (Ukwoma and Dike, 2017). Positive attitudes are highly dependent on perception and acceptance by academics. This issue was analysed by Fred Davis in the form of an acceptance model, a theory on technology acceptance and employment by users. Based on Davis's theory, user attitude toward a system determines if the individual implements or rejects the system. User attitude, in turn, is impacted by user's perception of the system's convenience and ease of use (Fred D Davis, 1989). Researchers' attitudes concerning IRs implementation in Malaysian universities needed to be explored because researchers are a vital factor for the success of IRs. Additionally, analysing factors that affect researchers' acceptance and the utilization of IRs can provide intuition for effective approaches to progress, implement and enhance IRs within universities. Thus, this paper aims to reveal knowledge concerning IRs acceptance and implementation by individuals via the application of the theoretical model and to define the factors impacting researchers' attitudes in utilizing IRs.

\section{Literature Review}

The following subsections briefly show the literature review section of the paper.

\section{Technology Acceptance Model}

Technology acceptance has been a topic of research over the past years to measure technology attitude or behavioral patterns of accepting technology (Malik, Suresh and Sharma, 2017). Researchers have gained more motivation to investigate the variables and factors that estimate the acceptance of modern technologies by users (Yadegaridehkordi et al. 2015). The Technology Acceptance Model (TAM) (Davis, 1989) is regarded as a dominating theory to conceptualize Information Systems (IS) utilization behavior and has been implemented influentially across a wide scope of information technologies and their relevant user populations (Razmak and Belanger, 2018; Bertrand and Bouchard, 2008). Upon examining 88 research papers via a meta-analysis method, King and $\mathrm{He}$ (2006) deduced that the TAM is a prosperous highly viable model. Thus, concerning the paper context, the TAM was applied to investigate researchers' attitude towards IRs usage acceptance for academic objectives.

TAM consists of two main components, which are Perceived Ease of Use (PEOU) and Perceived Usefulness (PU). Perceived Usefulness (PU) is described as "the degree to which a person believes that using a particular system would enhance his or her job performance" (Ajzen and Fishbein, 1980). Perceived Ease of Use (PEOU) is described as "the degree to which a person 
believes that using a particular system would be free of effort" (Davis, 1989). TAM suggests links of the mentioned central constructs with two other constructs, which are "behavioral intention to use the technology" (BI) and "attitude towards the technology" (ATT). ATT is described as "an individual's positive or negative feeling about performing the target behavior" (Fishbein and Ajzen, 1975). BI is described as "the degree to which a person has to formulate conscious plans to perform or not to perform some specified future behavior" (Warshaw and Davis, 1985). Figure 1 presents the TAM, showing that the impact of external variables was theorized to be mediated via PU and PEOU (Venkatesh and Bala, 2008).

\section{Research Model and Hypotheses Development}

The proposed research model is presented in Figure 1 with the exclusion of the actual behavior construct. This is because Behavioral Intention is regarded as an appropriate proxy and prominent predictor of actual behavior (Ajzen and Fishbein, 1980). PEOU and PU are the most vital factors of the technology acceptance model (Chen et al., 2003). Additionally, regarding the main links provided by TAM, numerous researchers have addressed external variables impacting PU and PEOU (Leong et al., 2018; Razmak and Belanger, 2018; Wang et al., 2018; Abdullah and Ward, 2016) to enhance TAM prediction power. Thus, external factors (also named antecedents of PEOU and PU) have a key role in describing technology adoption behavior (Abdullah and Ward, 2016). Venkatesh and Davis (1996) stated that "in order to be able to explain user acceptance and use, it is important to understand the antecedents of key TAM constructs, perceived ease of use and usefulness." Moreover, Mathieson (1991) stated that a TAM excluding external factors only provides vast information on user opinion regarding a system but does not provide "specific information that can better guide system development." In this regard, researchers have modified TAM with the addition of two external factors particularly Facilitating Conditions (FC) and Subjective Norm (SN) to base IRs use or acceptance.

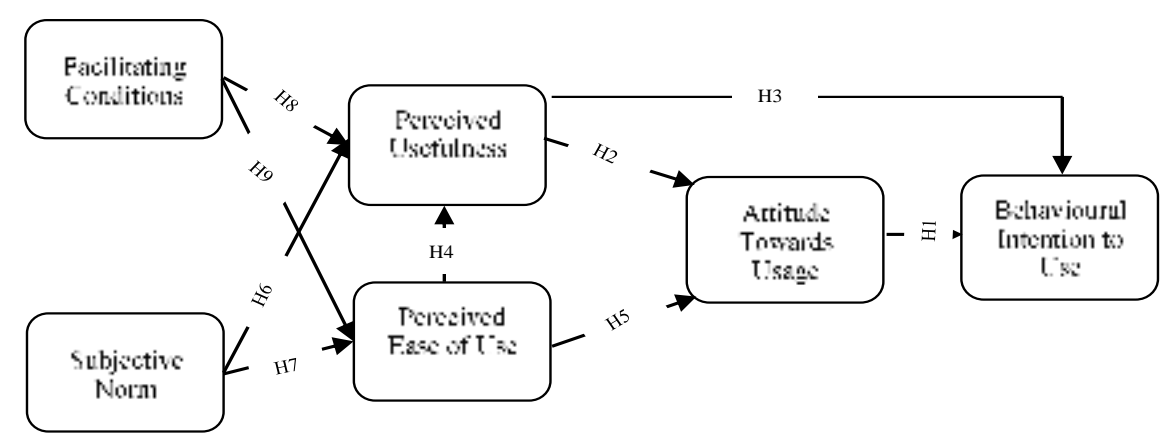

Figure 1. The technology acceptance model (Adapted from (Davis, 1989))

With the TAM, PEOU and PU are positioned to exhibit significant impact on ATT, which then effects the BI (Abdullah and Warn, 2016; Ching-Ter, Hajiyev, and Su, 2017; Razmak and Belanger, 2018; Teo, 2010). PU is a theoretical factor of TAM that has a considerable impact on technology. PU 
has an emphasis on the task accomplishment and determines the user's tendency to participate in technology usage as a result of the earned external reward (Septiani et al., 2017). Additionally, PEOU has proven to be of significant influence on PU (Leong et al., 2018; Teo 2010) based on the fact that whenever users consider a technology to be user-friendly, they are likely to consider it useful too. According to the discussions above, the following hypotheses are derived:

$\mathrm{H1}$ : Attitude toward use will have a significant influence on Researcher's intention to use IRs.

H2: Perceived usefulness will have a significant influence on attitude toward using IRs.

H3: Perceived usefulness will have a significant influence on behavior intention using IRs.

$\mathrm{H} 4$ : Perceived ease of use will have a significant influence on perceived usefulness of IRs.

H5: Perceived ease of use will have a significant influence on behavior intention using IRs.

Based on the studies conducted by Abdullah and Ward (2016), SN/SI has been implemented in 32 studies such that in 27 of these studies, its relationship with TAM is proved. Venkatesh et al. (2003) described SN as "the person's perception in that most people who are important to him think he should or should not perform the behavior in question." In this paper, a subjective norm is the extent to which an individual understands the demands of the "important" others on him/her to utilize the IRs. These findings are supported by Marcinkiewicz and Regstad (1996) who conducted studies on the impact of subjective norm on computer usage and concluded that subjective norm was not a predictive factor of computer usage as well as innovativeness, perceived relevance and self-competence. Moreover, previous studies found positive relationship between SN, PU, and PEOU (Abbas, 2016; Venkatesh \& Davis, 2000; Lai, 2017). From the discussions above, the hypotheses below are suggested:

H6: Subjective norm will have a significant influence on perceived usefulness of IRs. H7: Subjective norm will have a significant influence on perceived ease of use of IRs.

A facilitating condition described as "the degree to which a user feels that enough infrastructure is provided to support the use of a system" (Venkatesh et al., 2003). By way of explanation, FC includes factors that exist in the environment and impact an individual's perception of the degree of simplicity or difficulty to execute a task. For example, for technology usage in workplace technology use context, the FC consists of the training availability and support provision. The mentioned variable has been tested within numerous technology acceptances researches and proved to have a significant impact on technology acceptance (Teo, 2009). TAM3 regarded FC's role as PEOU antecedent (Agudo-Peregrina et al., 2014). Groves and Zemel (2000) concluded that FC supports information or materials, skills, training and administrative support and are regarded as vital factors that affect the utilization of instructional teaching technologies. Thus, it was posited that: H8: Facilitating conditions will have a significant influence on perceived usefulness of IRs.

H9: Facilitating conditions will have a significant influence on perceived ease of use of IRs.

\section{Research Method}

The PLS-SEM technique as statistical modelling technique was used for analyzing the measurement and structural model. To verify the model that has been extended, a questionnaire was designed in this research to obtain responses from researchers in University Putra Malaysia that was chosen as a target regarding their perception of IR. Therefore, the research objectives and types of information 
required by researchers were the basis of the survey instrument. This questionnaire includes 20 items that focus on all six factors. In order to measure each factor, a five-point Likert scale was utilized. The responses were chosen from (1=strongly disagree, 2=disagree, 3=neutral, 4=agree, 5=strongly agree). The data was analyzed via the PLS-SEM method with the addition of SmartPLS 3.0 statistical software. In total 90, respondents were participated in this study. As presented in Table 1, most of the 90 respondents were male (59\%), and most of the participants are aged 31-43 years, which constitute (53\%) of the respondents. Moreover, most respondents are PhD students (36.67\%). In addition, $(42.22 \%)$ of the respondents had moderate awareness on institutional repositories.

Table 1: Respondents' Demographic Information

\begin{tabular}{|c|c|c|}
\hline Demographic Information & Frequency & Percentage \\
\hline \multicolumn{3}{|l|}{ Gender } \\
\hline Male & 53 & $59 \%$ \\
\hline Female & 37 & $41 \%$ \\
\hline \multicolumn{3}{|l|}{ Age } \\
\hline$<30$ & 27 & $30 \%$ \\
\hline $31-43$ & 48 & $53.33 \%$ \\
\hline 44-55 & 9 & $10 \%$ \\
\hline$>56$ & 6 & $6.67 \%$ \\
\hline \multicolumn{3}{|l|}{ Occupation } \\
\hline Professor & 8 & $8.89 \%$ \\
\hline Senior Lecturer & 14 & $15.55 \%$ \\
\hline Lecturer & 15 & $16.68 \%$ \\
\hline Research fellow (Postdoc) & 4 & $4.44 \%$ \\
\hline Research assistant & 4 & $4.44 \%$ \\
\hline PhD student & 33 & $36.67 \%$ \\
\hline Another researcher & 12 & $13.33 \%$ \\
\hline \multicolumn{3}{|c|}{ Level of awareness of IR } \\
\hline Very High & 15 & $16.67 \%$ \\
\hline High & 26 & $28.89 \%$ \\
\hline Moderate & 38 & $42.22 \%$ \\
\hline Low & 11 & $12.22 \%$ \\
\hline
\end{tabular}

The responses from the participants on IR utilization purpose are presented in Figure 2 . The researchers showed that IRs are utilized for long term preservation (60) and to detect plagiarism (55). Other intentions included being up to date with recent information (54); it is an avenue to publish academic works (53); and to get information on relevant research areas (51). 


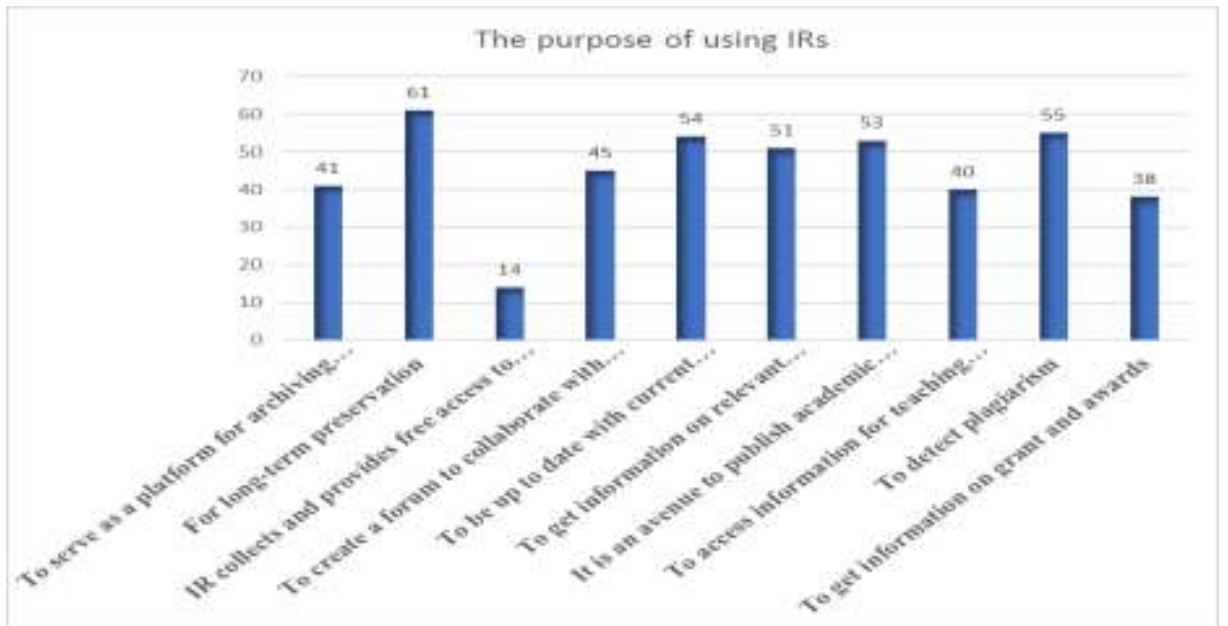

Figure 2. Responses on the purpose of using institutional repositories in UPM

The researchers were asked about the type of materials that they are interested in regarding the contribution to IRs. Figure 3 presents researcher's preferences in IR contribution. It clearly shows that most researchers were interested in the contribution of articles, thesis, journal bulletins, conference papers and books. The types of contributing material least interested in by researchers were exhibition materials and annual reports.

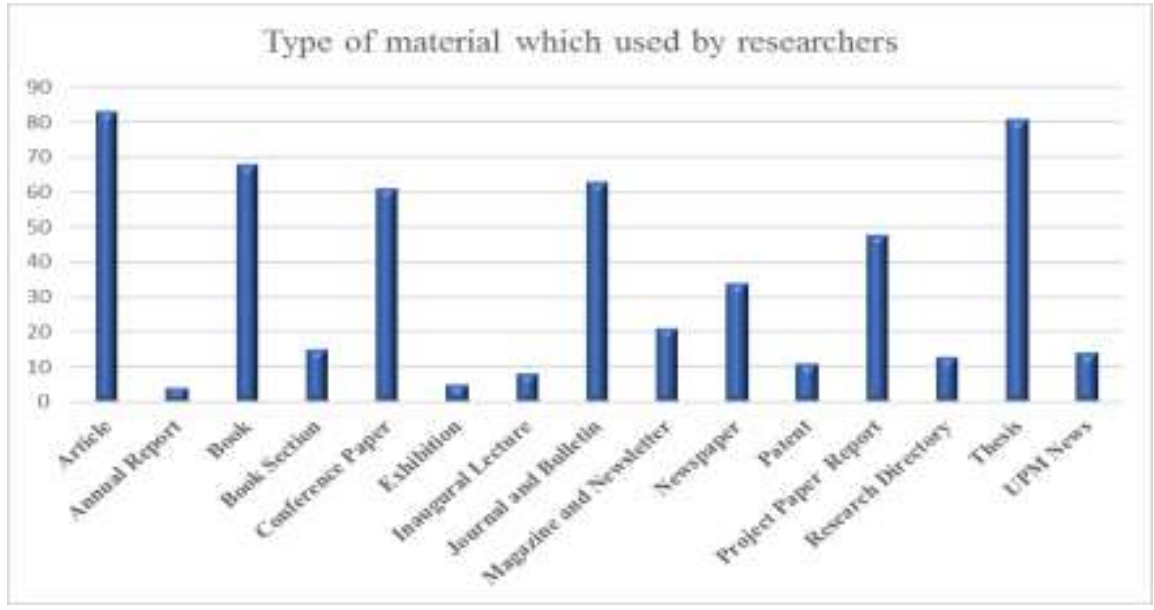

Figure 3. Researchers interest to contribute to IRs

\section{Measurement Validity}

For reliability and validity assessment of the questionnaire, several sets of tests have been done. As suggested by Hair et al., (2016), Cronbach's $\alpha$, composite reliability, internal consistency, and convergent validity and discriminate validity are the initial step in the assessment of the measurement model. Table 2 summarizes the result of these tests. The Partial Least Squares (PLS), a statistical technique, was used to estimate the measurement model of the study to test instrument validity and reliability. The reliability and validity of the constructs in the measurement model are approved via internal consistency, discriminant validity and convergent validity (Barclay et al., 1995; Hair Jr, 2013). The validity and reliability of the measurement model were supported by the following criterion: (a) corresponded constructs' items factor loadings must be greater than 0.7; (b) Average 
Variance Extracted (AVE) for all constructs must be greater than 0.5, and the AVE square root for every construct must be greater than correlations with other constructs of the model (Barclay et al., 1995; Fornell and Larcker, 1981; Chin, 1998); (c) Cronbach's alpha and composite reliability for all constructs must be over 0.7. Cronbach's alpha, composite reliability, the AVE and the item's factor loadings are presented in Table 2. Moreover, the correlations between the variables and each variable AVE are presented in Table 3. AVE square root is more than other correlations concerning every variable. Hence, the results support the reliability and validity of the measurement model.

Table 2: Results for the Measurement Model

\begin{tabular}{|c|c|c|c|c|c|}
\hline $\begin{array}{l}\text { Construct } \\
\text { Items }\end{array}$ & Indicator & $\begin{array}{l}\text { Factor } \\
\text { Loading } \\
(>0.7) a\end{array}$ & $\begin{array}{l}\text { Cronbach } \\
\alpha \\
(>0.7) a\end{array}$ & $\begin{array}{l}\text { Composite } \\
\text { Reliability } \\
(>0.7) \text { a }\end{array}$ & $\begin{array}{l}\text { Average } \\
\text { variance } \\
\text { extracted } \\
(>0.5) \text { a }\end{array}$ \\
\hline \multirow{4}{*}{$\begin{array}{l}\text { Attitude } \\
\text { Towards } \\
\text { Usage } \\
\text { (ATT) }\end{array}$} & ATT1 & 082 & \multirow[t]{4}{*}{0.83} & \multirow[t]{4}{*}{0.88} & \multirow[t]{4}{*}{0.66} \\
\hline & ATT2 & 0.76 & & & \\
\hline & ATT3 & 0.85 & & & \\
\hline & ATT4 & 0.872 & & & \\
\hline \multirow{3}{*}{$\begin{array}{l}\text { Behavioral } \\
\text { Intention } \\
\text { to Use (BI) }\end{array}$} & $\mathrm{BI} 1$ & 0.76 & \multirow[t]{3}{*}{0.78} & \multirow[t]{3}{*}{0.87} & \multirow[t]{3}{*}{0.70} \\
\hline & $\mathrm{B} 12$ & 0.88 & & & \\
\hline & $\mathrm{BI} 3$ & 0.86 & & & \\
\hline \multirow{3}{*}{$\begin{array}{l}\text { Facilitating } \\
\text { Conditions } \\
\text { (FC) }\end{array}$} & FC1 & 0.78 & \multirow[t]{3}{*}{0.72} & \multirow[t]{3}{*}{0.84} & \multirow[t]{3}{*}{0.64} \\
\hline & $\mathrm{FC2}$ & 0.79 & & & \\
\hline & FC3 & 0.83 & & & \\
\hline Perceived & PEOU1 & 0.81 & \multirow[t]{4}{*}{0.85} & \multirow[t]{4}{*}{0.90} & \multirow[t]{4}{*}{0.69} \\
\hline Ease of & PEOU2 & 0.84 & & & \\
\hline \multirow{2}{*}{$\begin{array}{l}\text { Use } \\
\text { (PEOU) }\end{array}$} & PEOU3 & 0.56 & & & \\
\hline & PEOU4 & 0.81 & & & \\
\hline \multirow{3}{*}{$\begin{array}{l}\text { Perceived } \\
\text { Usefulness } \\
\text { (PU) }\end{array}$} & PU1 & 0.79 & \multirow[t]{3}{*}{0.76} & \multirow[t]{3}{*}{0.86} & \multirow[t]{3}{*}{0.68} \\
\hline & PU2 & 0.88 & & & \\
\hline & PU3 & 0.80 & & & \\
\hline \multirow{3}{*}{$\begin{array}{l}\text { Subjective } \\
\text { Norm (SN) }\end{array}$} & SN1 & 0.79 & \multirow[t]{3}{*}{0.84} & \multirow[t]{3}{*}{0.90} & \multirow[t]{3}{*}{0.76} \\
\hline & SN2 & 0.93 & & & \\
\hline & SN3 & 0.89 & & & \\
\hline
\end{tabular}

Note: ${ }^{a}$ Indicates an acceptable level of reliability and validity.

All the constructs have AVE values greater than the value of 0.5 , which satisfied acceptable values. In addition, Fornel-Larker criterion was applied for the discriminant validity of the constructs. As shown in Table 3, all the amounts of the square roots of the constructs' AVE were greater than its correlation with other constructs. This specified that discriminant validity between the constructs was fulfilled. 
Table 3: Discriminant validity for the measurement model.

\begin{tabular}{lllllll}
\hline & ATT & BI & FC & PEOU & PU & SN \\
\hline ATT & $\mathbf{0 . 8 1}$ & & & & & \\
\hline BI & 0.77 & $\mathbf{0 . 8 4}$ & & & & \\
\hline FC & 0.67 & 0.64 & $\mathbf{0 . 8}$ & & & \\
\hline PEOU & 0.66 & 0.59 & 0.66 & $\mathbf{0 . 8 3}$ & & \\
\hline PU & 0.58 & 0.62 & 0.51 & 0.59 & $\mathbf{0 . 8 3}$ & \\
\hline SN & 0.64 & 0.61 & 0.66 & 0.56 & 0.56 & $\mathbf{0 . 8 7}$ \\
\hline
\end{tabular}

\section{Hypothesis Testing}

The next step after successful assessment of the measurement model is structural model assessment for examining the significance of the relations between constructs in the model. The hypotheses' test was used by testing the path coefficients, $p$-values and t-statistics analyses (see Table 4). The results of the structural model show that this model to be structurally good ( $2=0.642)$. Table 4 summarizes the results for hypothesis testing.

\section{Table 4: Summary of the Structural Model Assessment}

\begin{tabular}{lllllll}
\hline Hypothesis & Description & $\begin{array}{l}\text { Path } \\
\text { coefficient }\end{array}$ & $\begin{array}{l}\text { t- } \\
\text { Value }\end{array}$ & $\begin{array}{l}\text { p- } \\
\text { Value }\end{array}$ & $\begin{array}{l}\text { Significant } \\
\text { Level }\end{array}$ & Results \\
\hline $\mathrm{H} 1$ & $\mathrm{ATT} \rightarrow \mathrm{BI}$ & 0.619 & 6.369 & 0.000 & $* *$ & Supported \\
\hline $\mathrm{H} 2$ & $\mathrm{PU} \rightarrow \mathrm{ATT}$ & 0.298 & 2.493 & 0.013 & $*$ & Supported \\
\hline $\mathrm{H} 3$ & $\mathrm{PU} \rightarrow \mathrm{BI}$ & 0.264 & 2.737 & 0.006 & $* *$ & Supported \\
\hline $\mathrm{H} 4$ & $\mathrm{PEOU} \rightarrow \mathrm{PU}$ & 0.31 & 2.85 & 0.004 & $* *$ & Supported \\
\hline $\mathrm{H} 5$ & $\mathrm{PEOU} \rightarrow \mathrm{ATT}$ & 0.481 & 3.931 & 0.000 & $* *$ & Supported \\
\hline $\mathrm{H} 6$ & $\mathrm{SN} \rightarrow \mathrm{PU}$ & 0.398 & 3.095 & 0.002 & $* *$ & Supported \\
\hline $\mathrm{H} 7$ & $\mathrm{SN} \rightarrow \mathrm{PEOU}$ & 0.104 & 1.069 & 0.285 & $*$ & Not \\
\hline $\mathrm{H} 8$ & $\mathrm{FC} \rightarrow \mathrm{PU}$ & 0.249 & 1.943 & 0.052 & $*$ & Not \\
\hline
\end{tabular}

The structural model result indicates that there is a significant positive relationship between ATT and BI. The results $(\beta=0.619, \mathrm{t}$-value $=6.369, \mathrm{P}<0.01)$ provided evidence to support this hypothesis. Thus, intention to use IR is significantly influenced by ATT and H1 is supported. This finding is consistent with similar studies in the literature (Ukwoma \& Dike, 2017) the similar conclusion of academics had the attitude toward using IR. This study suggested that there is a significant and positive relationship between PU and ATT and PEOU and ATT the results of the hypotheses test $(\beta=0.298$, $\mathrm{t}$-value $=2.493, \mathrm{P}<0.05)$ and $(\beta=0.481$, $\mathrm{t}$-value $=3.931, \mathrm{P}<0.01)$ also support this indication. The previous study by (Ukwoma \& Dike, 2017) supported this claim and as highlighted in the TAM, ATT is influenced by the PEOU and PU of a system. So, the hypotheses $\mathrm{H} 2$ and $\mathrm{H} 5$ were supported. The research findings in the study indicate that $\mathrm{PU}$ has positive and significant influence on $\mathrm{BI}(\beta=0.264$, $\mathrm{t}$-value $=2.737, \mathrm{P}<0.01), \mathrm{H} 3$ was supported. This result is accordance with previous study by (Asadi et al., 2017; Çelik, 2011) that have been conducted on cloud computing and online shopping. The fourth hypothesis $(\mathrm{H} 4)$ states that PEOU has a positive effect on 
$\mathrm{PU}$, this claim also was supported in this study $(\beta=0.31, \mathrm{t}$-value $=2.85, \mathrm{P}<0.01)$. This result is consistence with prior study, which conducted on software adoption behavior (Hsu, Wang, \& Chiu, 2009). The hypotheses (H6) indicated that SN has positive significant influence on $P U(\beta=0.398, t-$ value $=3.095, \mathrm{P}<0.01$ ), which is consistence with prior studies (Abbas, 2016; Venkatesh et al., 2003). The results of the hypotheses $(\mathrm{H} 7$ and $\mathrm{H} 8$ ) indicate that there is not significant relationship between SN and $F C(\beta=0.104$, $t$-value $=1.069, P<0.05)$ and $F C$ and $P U(\beta=0.249, t$-value $=1.943, P<0.05)$, so they were rejected in this study. The $\mathrm{H} 9$ indicates that $\mathrm{FC}$ has positive and significant influence on PEOU $(\beta=0.43$, $t$-value $=4.88, P<0.01), \mathrm{H} 9$ is supported. The result of this study is consistence with ( Agudo-Peregrina et al., 2014). Among all the constructs, ATT has considered as a most influential factor which had the highest path-coefficient and t-statistics. It reveals that researchers have more attitude toward using and submitting their work on IR. This finding is similar with (Ukwoma \& Dike, 2017; Wicaksana, Asandimitra, 2018), who indicated that academics had positive influence towards utilization of institutional repositories.

\section{Conclusions and Future Work}

The main aim of this research was to determine researchers' intentions and attitude concerning the utilization of institutional repositories. Accordingly, a model with nine hypotheses was developed through a modified Technology Acceptance Model. The model was evaluated by the data collected from a sample of 90 researchers at the UPM. As proved in the result's section, most researchers are aware of IRs and have a positive attitude in submitting their academic content on the IR to aid in increasing university ranking and citation impact of their work. This study proved that books, thesis, and articles comprise of the most material interested in by researchers for IR contribution. The results of the study indicate that from nine proposed hypotheses, seven were accepted and two of them were rejected. Moreover, the findings from the structural analysis revealed that ATT was considered as a most influential factor that influenced on behaviour intention. Which This finding is consistent with several prior studies that have identified ATT as key determinants of behaviour intention to use technology (Asadi et al., 2017; Khatatneh \& Teh, 2018). Results from the representative sample data show that IRs were formed for long term preservation, to detect plagiarism, being up to date with recent information, avenue to publish academic works, and to get information on relevant research areas. The researchers suggest that future research can be carried out to better exploring the researchers' behavioural intention toward using institutional repositories in Malaysian research universities. As mentioned above, the focus of this study is on researchers. Further investigation is needed to test the model among different subjects, such as library staff and IT specialists.

\section{References}

Abbas, H. A. (2016). Subjective Norm as Antecedents of Consumers' Behavioral Intentions to Use Smart Phones in Arab World. Journal of Mobile Technologies, Knowledge and Society.

Abdullah, F., \& Ward, R. (2016). Developing a General Extended Technology Acceptance Model for ELearning (GETAMEL) by analysing commonly used external factors. Computers in Human Behavior, 56, 238-256.

Agudo-Peregrina, A. F., Hernandez-Garcia, A., \& Pascual-Miguel, F. J. (2014). Behavioral intention, use behavior and the acceptance of electronic learning systems: Differences between higher education and lifelong learning. Computers in Human Behavior, 34, 301-314. 
Ajzen, I., \& Fishbein, M. (1980). Understanding attitudes and predicting social. Behaviour. Englewood Cliffs, NJ: Prentice-Hall.

Anenene, E. E., Alegbeleye, G. B., \& Oyewole, O. (2017). Factors contributing to the adoption of institutional repositories in Universities in South- West Nigeria: Perspectives of library staff. Library Philosophy and Practice, 2017(1).

Asadi, S., Nilashi, M., Husin, A. R. C., \& Yadegaridehkordi, E. (2017). Customers perspectives on adoption of cloud computing in banking sector. Information Technology and Management, 18(4), 305-330.

Barclay, D., Higgins, C., \& Thompson, R. (1995). The partial least squares (PLS) approach to causal modeling: Personal computer adoption and use as an illustration. Technology Studies, 2(2), 285309.

Bertrand, M., \& Bouchard, S. (2008). Applying the technology acceptance model to vr with people who are favorable to its use. Journal of Cyber Therapy and Rehabilitation, 1(2), 200-207.

Çelik, H. (2011). Influence of social norms, perceived playfulness and online shopping anxiety on customers' adoption of online retail shopping: An empirical study in the Turkish context. International Journal of Retail \& Distribution Management, 39(6), 390-413.

Chen, Y., Lin, Y., Yeh, R. C., \& Lou, S. (2013). Examining factors affecting college students' intention to use web-based instruction systems: Towards an integrated model. The Turkish Online Journal of Educational Technology, 12(2), 111-122.

Chin, W. W. (1998). The partial least squares approach to structural equation modeling. Modern Methods for Business Research, 295(2), 295-336.

Ching-Ter, C., Hajiyev, J., \& Su, C. R. (2017). Examining the students' behavioral intention to use elearning in Azerbaijan? The General Extended Technology Acceptance Model for E-learning approach. Computers and Education, 111, 128-143.

Davis, F. D. (1989). Perceived Usefulness, Perceived Ease of Use, and User Acceptance of. MIS Quarterly, 13(3), 319-340.

Fishbein, M., \& Ajzen, I. (1975). Belief, attitude, intention and behavior: An introduction to theory and research. MA: Addison-Wesley.

Fornell, C., \& Larcker, D. F. (1981). Structural equation models with unobservable variables and measurement error: Algebra and statistics. Journal of Marketing Research, 382-388.

Groves, M. M., \& Zemel, P. C. (2000). Instructional technology adoption in higher education: An action research case study. International Journal of Instructional Media, 27(1), 57-65.

Hair, J. J. F. (2013). A primer on partial least squares structural equation modeling (PLS-SEM). Sage Publications.

Hsu, M. K., Wang, S. W., \& Chiu, K. K. (2009). Computer attitude, statistics anxiety and self-efficacy on statistical software adoption behavior: An empirical study of online MBA learners. Computers in Human Behavior, 25(2), 412-420.

Khatatneh, N. A. K., \& Teh, K. S. M. (2018). The Effects of Computerized Learning Games on the Third Grade Students in Karak Governorate. International Journal of Academic Research in Progressive Education and Development, 7(2), 96-111.

King, W. R., \& He, J. (2006). A meta-analysis of the technology acceptance model. Information \& Management, 43(6), 740-755. 
INTERNATIONAL JOURNAL OF ACADEMIC RESEARCH IN BUSINESS AND SOCIAL SCIENCES

Vol. 9, No. 13, Special Issue: Revolutionizing Education: Challenges, Innovation, Collaboration., 2019, E-ISSN: 2222-6990 @ 2019 HRMARS

Lai, P. C. (2017). The Literature Review of Technology Adoption Models and Theories For The Novelty Technology. JISTEM-Journal of Information Systems and Technology Management, 14(1), 21-38.

Leong, L. W., Ibrahim, O., Dalvi-Esfahani, M., Shahbazi, H., \& Nilashi, M. (2018). The moderating effect of experience on the intention to adopt mobile social network sites for pedagogical purposes: An extension of the technology acceptance model. Education and Information Technologies.

Malik, A., Suresh, S., \& Sharma, S. (2017). Factors influencing consumers' attitude towards adoption and continuous use of mobile applications: A conceptual model. Procedia Computer Science, 122, 106-113.

Marcinkiewicz, H. R., \& Regstad, N. G. (1996). Using subjective norms to predict teachers' computer use. Journal of Computing in Teacher Education, 13(1), 27-33.

Mathieson, K. (1991). Predicting user intentions: comparing the technology acceptance model with the theory of planned behavior. Information Systems Research, 2(3), 173-191.

Ngure, M., Sharif, A., \& Gatiti, P. (2015). Cross-border Implementation of Institutional Repository: A case of Aga Khan University, The IFLA Library. Retrieved from http://library.ifla.org/ [Google Scholar]

Razmak, J., \& Bélanger, C. (2018). Using the technology acceptance model to predict patient attitude towards personal health records in regional communities. Information Technology \& People, 0000.

Septiani, R., Handayani, P. W., \& Azzahro, F. (2017). Factors that Affecting Behavioral Intention in Online Transportation Service: Case study of GO-JEK. Procedia Computer Science, 124, 504-512.

Singeh, W. F., Abrizah, A., \& Karim, H. A. N. (2013). Malaysian authors' acceptance to self-archive in institutional repositories. The Electronic Library, 31(2), 188-207.

Teo, T. (2009). The Impact of Subjective Norm and Facilitating Conditions on Pre-Service Teachers' Attitude toward Computer Use: A Structural Equation Modeling of an Extended Technology Acceptance Model. Journal of Educational Computing Research, 40(1), 89-109.

Teo, T. (2010). Examining the influence of subjective norm and facilitating conditions on the intention to use technology among pre-service teachers: A structural equation modeling of an extended technology acceptance model. Asia Pacific Education Review, 11(2), 253-262.

Ukwoma, S. ., \& Dike, V. W. (2017). Academics' Attitudes toward the Utilization of Institutional Repositories in Nigerian Universities. Portal: Libraries and the Academy, 17(1), 17-32.

Ukwoma, S. C., \& Okafor, V. N. (2017). Institutional Repository in Nigerian Universities: Trends and Development. Library CollectionsOnline) Journal Library Collections, 40(1-2), 1464-9055.

Venkatesh, M. G. Morris, B. D., Gordon, F. D. D. (2003). User acceptance of information technology: toward a unified view. MIS Quarterly 27 (3), 27(3), 425-478.

Venkatesh, V., \& Davis, F. (2000). Theoretical acceptance extension model: Field four studies of the technology longitudinal. Management Science, 46(2), 186-204.

Venkatesh, V., \& Davis, F. D. (1996). A model of the antecedents of perceived ease of use: Development and test. Decision Sciences, 27(3), 451-481.

Wang, Y., Wang, S., Wang, J., Wei, J., \& Wang, C. (2018). An empirical study of consumers ' intention to use ride - sharing services : using an extended technology acceptance model. Transportation.

Warshaw, P. R., \& Davis, F. D. (1985). Disentangling behavioral intention and behavioral expectation. Journal of Experimental Social Psychology, 21(3), 213-228. 
INTERNATIONAL JOURNAL OF ACADEMIC RESEARCH IN BUSINESS AND SOCIAL SCIENCES

Vol. 9, No. 13, Special Issue: Revolutionizing Education: Challenges, Innovation, Collaboration., 2019, E-ISSN: 2222-6990 @ 2019 HRMARS

Wicaksana, S.B., Asandimitra, N. (2018). Halloween Effect in Indonesia Stock Exchange, International Journal of Academic Research in Accounting, Finance and Management Sciences 8 (3): 118-127.

Yadegaridehkordi, E., lahad, N. A., \& Asadi, S. (2015). Cloud computing adoption behaviour: an application of the technology acceptance model. Journal of Soft Computing and Decision Support Systems, 2(2), 11-16. 